\title{
ENSINO DE PONTUAÇÃO EM UMA COLEÇÃO DIDÁTICA DE PORTUGUÊS: UMA ANÁLISE DIALÓGICA
}

\section{Anderson Cristiano da Silva ${ }^{1}$}

Resumo: Esta pesquisa é um recorte de nossa tese que analisou as atividades didáticas relativas aos sinais de pontuação presentes nos volumes do $6^{\circ}$ ao $9^{\circ}$ ano de duas coleções: Português: uma proposta para o letramento e Português: linguagens, na qual nos restringimos a apresentar apenas essa última. Para alicerçar nossa investigação, a pesquisa teve como arcabouço teórico as contribuições da Análise Dialógica do Discurso (ADD), concebida a partir dos trabalhos de Bakhtin e o Círculo, elegendo relações dialógicas como conceito-chave. Da perspectiva organizacional, foram apresentados dois eixos: (i) apresentação do conceito-chave elencado; (ii) a descrição e análise das atividades didáticas sobre o ensino da pontuação na coleção elencada. Em nossas considerações, observamos a concentração do conteúdo em um único volume, o que pode implicar alguns aspectos negativos, como, a responsabilidade do professor daquela série em identificar e aprofundar possíveis lacunas que a coleção tenha deixado sobre a respeito dos sinais de pontuação.

Palavras-chave: Sinais de pontuação; Livro didático de português; Análise dialógica do discurso.

\footnotetext{
${ }^{1}$ Pontifícia Universidade Católica de São Paulo/ Programa de Pós-Graduados em Linguística Aplicada e Estudos da Linguagem (LAEL), Rua Monte Alegre, 984, Perdizes, São Paulo -SP, Brasil. E-mail: andcs23@hotmail.com
} 